\section{Adventitious Rooting of Stem Cuttings of Yellow-flowered Magnolia Cultivars is Influenced by Time after Budbreak and Indole-3-butyric Acid}

\author{
Jyotsna Sharma, ${ }^{1}$ Gary W. Knox, ${ }^{2}$ and Maria Lucia Ishida ${ }^{3}$ \\ Department of Environmental Horticulture, University of Florida, Quincy, \\ FL 32351
}

Additional index words. clonal propagation, weeks after budbreak, auxin, vegetative propagation, Magnoliaceae

\begin{abstract}
Certain cultivars of magnolia are desirable in landscapes for their uncommon yellow flowers. While cultivars derived from Magnolia acuminata L. (cucumbertree magnolia) are difficult to propagate by stem cuttings, some with mixed parentage appear easier to propagate in this manner. We propagated six yellow-flowered cultivars vegetatively by applying $0,8,16$, or $30 \mathrm{~g} \cdot \mathrm{kg}^{-1}(0,8,000,16,000$, or $30,000 \mathrm{ppm})$ indole-3-butyric acid (IBA) in talc to bases of terminal stem cuttings collected 5, 7, 9, or 11 weeks after budbreak. Mean rooting percentage over all cultivars increased from $12 \%$ (in the absence of IBA) to $34 \%$ (after application of $30 \mathrm{~g} \cdot \mathrm{kg}^{-1}$ IBA). Rooting percentage and basal stem diameter of a cutting did not seem related. For each collection date, more cuttings of 'Ivory Chalice' and 'Yellow Lantern' developed roots than the other cultivars. More roots $(\operatorname{mean}=5)$ developed on cuttings of 'Yellow Lantern' collected 5 weeks after budbreak or when treated with $30 \mathrm{~g} \cdot \mathrm{kg}^{-1}$ IBA than the other cultivars. 'Butterflies' largely remained unresponsive, whereas rooting of 'Golden Sun,' 'Hot Flash,' and 'Maxine Merrill' collected 5 weeks after budbreak was $31 \%, 22 \%$, and $28 \%$, respectively. When data were analyzed separately for selected cultivars, $63 \%$ rooting was observed among cuttings of 'Ivory Chalice' collected 7 weeks after budbreak. Rooting percentage was higher (22\%) among cuttings of 'Hot Flash' collected 5 or 7 weeks after budbreak in comparison to later collection dates, but harvest date did not influence rooting of 'Yellow Lantern,' which ranged from $44 \%$ to $59 \%$. Collection of stem cuttings early in the growing season ( 5 weeks after budbreak) was beneficial (31\% rooting) for inducing rooting among cuttings of 'Golden Sun.' We conclude that 'Ivory Chalice' and 'Yellow Lantern' are promising choices for growers interested in clonal propagation of yellow-flowered cultivars of magnolia. To maximize rooting among these cultivars, terminal cuttings should be collected within 5 to 11 weeks

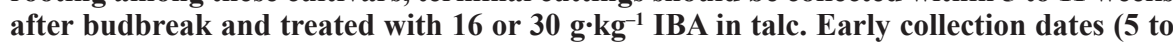
7 weeks after budbreak) improved rooting among cuttings of other cultivars but these, particularly 'Butterflies,' remain variably recalcitrant and merit further study.
\end{abstract}

Species, varieties, and cultivars of magnolia are popular flowering trees that can be propagated by seed (species and varieties only), softwood cuttings, semi-hardwood cuttings, micropropagation, layering, budding, and grafting (Callaway, 1994; Dirr and Heuser, 1987). Plants are valued for their showy flowers, foliage, or fruits, but all taxa are not equally easy to propagate, nor do they respond similarly to a single method of propagation (Hartmann et al., 2002).

Demand for yellow-flowered selections of magnolia has increased, and a large number of hybrids are derived from Magnolia acuminata and M. denudata Desr. (yulan magnolia) (Dirr, 1998). Other taxa used to obtain yellow-flowered hybrids and cultivars are $M$.

Received for publication 26 July 2005. Accepted for publication 11 Nov. 2005. We extend our gratitude to John Zadakis for providing technical assistance throughout this study.

${ }^{1}$ Assistant professor. To whom reprint requests should be addressed; e-mail Jyotsna@ufl.edu.

${ }^{2}$ Professor.

${ }^{3}$ Biological scientist. kobus DC. (kobus magnolia), M. acuminata L. var. subcordata (Spach) Dandy (yellow cucumbertree), and Magnolia $\times$ soulangiana Soul.-Bod. (saucer magnolia) (Knox, 2001). Hybrids derived from M. acuminata tolerate variable soil conditions and exhibit delayed flowering, which prevents frost damage to flowers (Callaway, 1994). Nevertheless, because stem cuttings of M. acuminata and $M$. denudata do not root easily, many of their yellow-flowered hybrids also carry this trait, and rooting generally is less than $40 \%$ (Dirr and Heuser, 1987; Knox, 2001; Owen et al., 2001). Consequently, these primarily are propagated by budding, grafting, or tissue culture. For most growers, however, inducing root formation on stem cuttings is the most feasible method of vegetative propagation.

Despite clonal propagation, some variation in flower color is observed among yellow-flowered cultivars of magnolia in northern Florida, and color can vary from year to year (Knox, 2001), due perhaps to variation in weather and/or soil conditions (Tessmer, 1998). The yellow color (listed in the order of decreasing color intensity) is consistently more intense among flowers of 'Butterflies,' 'Golden Sun,' 'Maxine Merrill,' and 'Hot Flash' compared to the flower color of 'Ivory Chalice' and 'Yellow Lantern,' which are cream or pale yellow (G.W. Knox, personal observation). These cultivars are of interest to growers and consumers, but experimental methods and statistical treatment of results have not been reported for their vegetative regeneration.

Physiological developmental stage of the cuttings or time of year when cuttings are harvested influences rooting among cuttings of many woody species (Hartmann et al., 2002). While stem cuttings of certain plants produce roots easily at any time of year, species and cultivars of magnolia generally have a narrow 'window of rootability,' which also may vary among cultivars (Dirr and Heuser, 1987). Deciduous taxa of magnolia produce roots when softwood cuttings are used (Ellis, 1988; Hartmann et al., 2002), and although some cultivars have been rooted by using softwood cuttings (Ellis, 1988), experimental methods and results are not available, to our knowledge, to indicate the sensitivity of abovementioned yellow-flowered cultivars to time of cutting collection.

Auxins induce adventitious rooting on stem cuttings of many woody plants, including species and cultivars of magnolia (Hartmann, et al., 2002). A range from 5 to $20 \mathrm{~g} \cdot \mathrm{kg}^{-1}$ IBA in talc often is used to propagate cuttings of magnolia, but variation among taxa is known (Dirr and Heuser, 1987; Ellis, 1988; Hartmann et al., 2002). Although the effect of indole-3-butyric acid (IBA) on cuttings of the abovementioned yellow-flowered cultivars is unknown, some general, non-statistical reports describe vegetative propagation of a few cultivars and parent taxa. For example, rooting of some yellowflowered cultivars, including 'Hot Flash' and 'Ivory Chalice,' ranged from $50 \%$ to $100 \%$ (Knox, 2001), but the influence of IBA, number of cuttings, physiological stage, date of collection, and environmental conditions during the experiment were not reported. Among parent taxa, there are no reports, to our knowledge, to describe root formation on cuttings of $M$. acuminata, which is one of the parents of all yellow-flowered cultivars included in this study. However, $85 \%$ to $100 \%$ of the wounded cuttings of $M$. denudata collected in early June in the northeastern U.S. developed roots after application of 3 to $8 \mathrm{~g} \cdot \mathrm{kg}^{-1}$ IBA, while a range from 8 to $16 \mathrm{~g} \cdot \mathrm{kg}^{-1}$ IBA was recommended to induce root formation on cuttings of $M$. $\times$ soulangiana cultivars (Dirr and Heuser, 1987). Up to $80 \%$ rooting frequency also was reported among wounded softwood cuttings of $M$. kobus DC. var. borealis Sarg. (borealis kobus magnolia) after $20 \mathrm{~g} \cdot \mathrm{kg}^{-1}$ IBA was applied in talc (Dirr and Heuser, 1987). These results, while encouraging, do not describe replicable experimental methods (number of cuttings, time of collection in relation to budbreak, length and basal stem diameter of cuttings, environmental conditions under which cuttings were rooted, etc.), nor do they include statistical treatment of data.

Rooting among stem cuttings of magnolia apparently is influenced by physiological de- 
Table 1. Parentage, date of budbreak in 2004, and dates on which cuttings were collected for assessing rooting capacity among yellow-flowered cultivars of magnolia.

\begin{tabular}{|c|c|c|c|}
\hline Cultivar & Parentage & $\begin{array}{c}\text { Date of } \\
\text { budbreak }\end{array}$ & $\begin{array}{c}\text { Collection date } \\
\text { (weeks after budbreak) }\end{array}$ \\
\hline \multirow[t]{4}{*}{ 'Butterflies' (USPP\#7456) } & Magnolia acuminata 'Fertile Myrtle' $\times$ Magnolia denudata 'Sawada's Cream' & 15 Mar. & 20 Apr. (5) \\
\hline & & & 4 May (7) \\
\hline & & & 18 May (9) \\
\hline & & & 1 June (11) \\
\hline \multirow[t]{4}{*}{ 'Golden Sun' } & M. acuminata $\times$ M. denudata & 15 Mar. & 20 Apr. (5) \\
\hline & & & 4 May (7) \\
\hline & & & May $18(9)$ \\
\hline & & & 1 June (11) \\
\hline \multirow[t]{4}{*}{ 'Hot Flash' } & Magnolia $\times$ brooklynensis 'Woodsman' $\times[($ M. acuminata $\times$ M. denudata $)$ 'Elizabeth'] & 15 Mar. & 20 Apr. (5) \\
\hline & & & 4 May (7) \\
\hline & & & 18 May (9) \\
\hline & & & 1 June (11) \\
\hline \multirow[t]{4}{*}{ 'Ivory Chalice' } & M. acuminata $\times$ M. denudata & 8 Mar. & 13 Apr. (5) \\
\hline & & & 27 Apr. (7) \\
\hline & & & 11 May (9) \\
\hline & & & 25 May (11) \\
\hline \multirow[t]{4}{*}{ 'Maxine Merrill' } & M. acuminata var. subcordata 'Miss Honeybee' $\times$ Magnolia kobus var. loebneri 'Merrill' & 15 Mar. & 20 Apr. (5) \\
\hline & & & 4 May (7) \\
\hline & & & 18 May (9) \\
\hline & & & 1 June (11) \\
\hline \multirow[t]{4}{*}{ 'Yellow Lantern' } & M. acuminata var. subcordata $\times$ Magnolia $\times$ soulangiana 'Alexandrina' & 8 Mar. & 13 April (5) \\
\hline & & & 27 Apr. (7) \\
\hline & & & 11 May (9) \\
\hline & & & 25 May (11) \\
\hline
\end{tabular}

velopment stage of the cutting. IBAapplication also influences subsequent root development on cuttings of many woody taxa, including species and cultivars of magnolia. In this study, we assessed adventitious rooting among stem cuttings of six yellow-flowered, deciduous cultivars of magnolia to determine the effect of cultivar, collection date, and IBA.

\section{Materials and Methods}

A factorial arrangement of six cultivars of magnolia ('Butterflies,' 'Golden Sun,' 'Hot Flash,' 'Ivory Chalice,' 'Maxine Merrill,' and 'Yellow Lantern'), four collection dates, and four IBA treatments was established in a completely randomized design. Mature (reproductive phase) field-planted trees were used as donor plants (Table 1). Stem cuttings were collected 5 (earliest date when suitable cuttings could be harvested), 7, 9, or 11 weeks after budbreak, corresponding to softwood through semi-hardwood stages of growth. Budbreak in 2004 was observed on 8 Mar. on trees of 'Ivory Chalice' and 'Yellow Lantern,' and on 15 Mar. on trees of 'Butterflies,' 'Golden Sun,' 'Hot Flash,' and 'Maxine Merrill.' In total, 32 terminal cuttings with 2 to 4 nodes were collected from each cultivar on each collection date, and basal stem diameter of each cutting was recorded. Two fully expanded leaves were retained on each cutting, but their distal halves were removed. Each cutting was wounded by scraping the basal 1 to $2 \mathrm{~cm}$ by using a single-edge blade to expose the cambium. Eight stem cuttings of each cultivar then were assigned randomly to each of the four auxin treatments: 1) untreated $\left[0 \mathrm{~g} \cdot \mathrm{kg}^{-1}(0 \mathrm{ppm})\right]$; 2) $8 \mathrm{~g} \cdot \mathrm{kg}^{-1}(8,000 \mathrm{ppm})$; 3$) 16 \mathrm{~g} \cdot \mathrm{kg}^{-1}(16,000$ $\mathrm{ppm})$; or $30 \mathrm{~g} \cdot \mathrm{kg}^{-1}(30,000 \mathrm{ppm})$ indole-3butyric acid (IBA) in talc (Hormex \#8, \#16, and \#30, respectively; Brooker Chemical, Chatsworth, Calif.). Basal $5 \mathrm{~cm}$ of each cutting was inserted into each plastic container(SR225,
The Lerio Corp, Mobile, Ala; volume $=227$ $\mathrm{cm}^{3}$ ) containing a 1:1 mixture (by volume) of peat (Berger Peat Moss, Inc., St. Modeste, Que., Canada) and coarse perlite (Harborlite Corporation, Lompoc, Calif.); this served as an experimental unit.

Potted cuttings were placed under a programmable intermittent mist system (Gemini 6A, Phytotronics, Inc., Earth City, Mo.) equipped with a light sensor. Tap-water mist was delivered for $6 \mathrm{~s}$ every 6 min during the natural photoperiod (irradiance $>107.6 \mathrm{Lu}$ $\left.\mathrm{men} / \mathrm{m}^{2}\right)$. Mist was emitted at 35 to $45 \mathrm{psi}$ via brass deflector-type nozzles (Reed S. Kofford Co., Pleasant Hill, Calif.) with $1.0 \mathrm{~mm}$ orifice. Ambient temperature and temperature of the substrate were recorded every $1 \mathrm{~h}$ by using a HOBO datalogger (Onset Computer, Bourne, Mass.). Mean day/night air and substrate temperatures were $29 / 24{ }^{\circ} \mathrm{C}$ and $27 / 22{ }^{\circ} \mathrm{C}$, respectively.

Data were recorded 10 weeks after the respective cuttings were inserted. Relative quality of root systems was rated visually by using values ranging from 0 to 5 , where $0=$ neither callus nor roots were observed on the base of the cutting, or the base was decayed; 1 $=$ presence of callus but roots absent; $2=$ one or two roots $\geq 0.5 \mathrm{~cm}$ in length; $3=$ few, relatively short roots; 4 = several, developed roots; and 5 = many, well developed roots. Number of primary roots was counted and the length of the longest root was determined. Roots from each cutting were removed subsequently, dried at $65^{\circ} \mathrm{C}$ for $72 \mathrm{~h}$, and then weighed. A cutting was considered rooted if it had at least one root $\geq 0.5 \mathrm{~cm}$ in length (rating of 2 or higher).

Data for all dependent variables (visual rating of roots, root count, and proportion of cuttings that rooted) were subjected to analysis of variance (ANOVA) by using the GLM procedure in SAS/STAT (version 8.02, SAS Institute, Inc., Cary, N.C.). Rooting proportions were arcsin transformed before analyses, but nontransformed, percentage data are presented. The main effects of cultivar, collection date (weeks after budbreak), and concentration of IBA, along with all interactions of these, were included as terms in the model. Data for 'Ivory Chalice,' 'Golden Sun,' 'Hot Flash,' and 'Yellow Lantern' also were analysed individually to test the main effects of collection date and concentration of IBA and their interaction. When appropriate, means were separated by using Fisher's LSD $(\alpha=0.05)$. We used the CORR procedure to determine Pearson's correlation coefficient for root count and rating of roots.

\section{Results and Discussion}

Among the 96 factorial treatment combinations, a three-way interaction was not detected among cultivar, collection date (weeks after budbreak), and concentration of IBA and therefore, did not influence rooting percentage. A two-way interaction between cultivar and collection date occurred, but the frequency of rooting was not influenced by an interaction between cultivar and IBA. The main effect of IBA was significant.

Highest rooting for 'Golden Sun' and 'Maxine Merrill' occurred when cuttings were collected 5 weeks after budbreak $(31 \%$ and $28 \%$, respectively; Fig. 1), but cuttings of 'Hot Flash' harvested 5 or 7 weeks after budbreak rooted similarly (22\%). Rooting percentages were about twice as high among cuttings of 'Ivory Chalice' and 'Yellow Lantern' collected 7 (63\% and $59 \%$, respectively) or $9(56 \%$ and $53 \%$, respectively) weeks after budbreak. Cuttings that were harvested 11 weeks after budbreak often had the lowest rooting compared to earlier collection dates (Fig. 1), but $<5 \%$ rooting occurred among cuttings of 'Butterflies' regardless of the time of collection. 'Ivory Chalice' and 'Yellow Lantern' seem most suited for vegetative propagation by using 


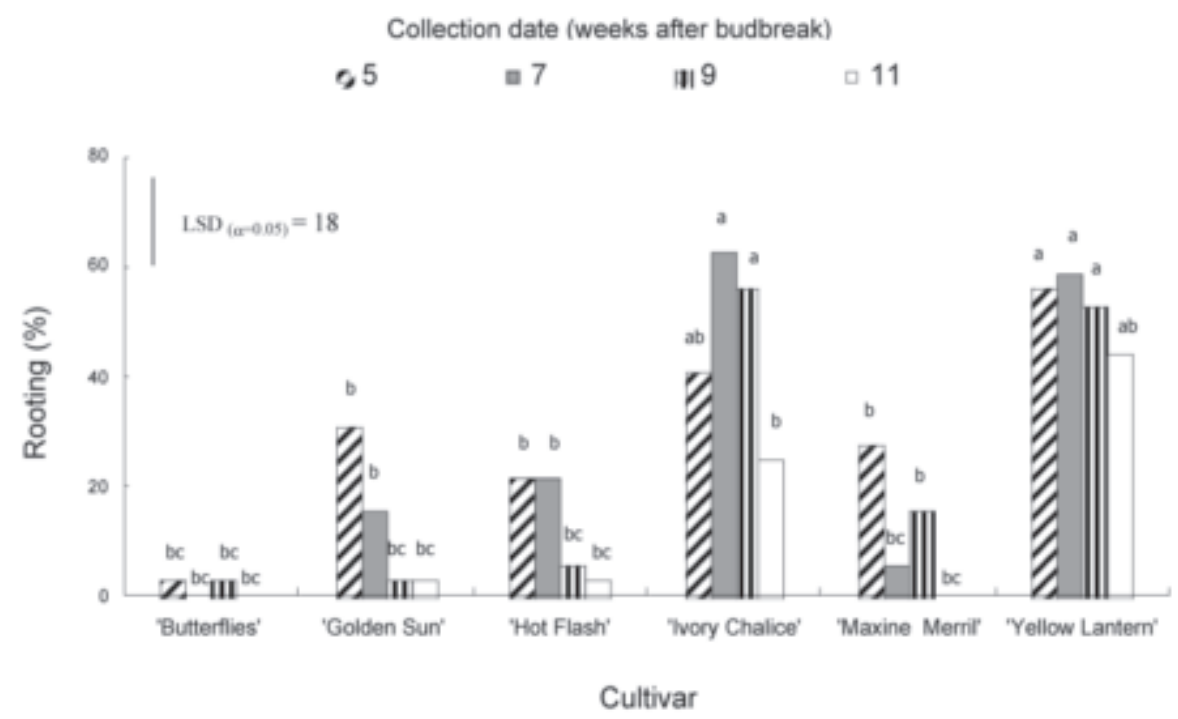

Table 2. Basal stem diameter and rooting percentage were affected by an interaction of cultivar and collection date. However, stem diameter at the base and rooting percentage did not appear to be related to each other.

\begin{tabular}{|c|c|c|c|}
\hline Cultivar & $\begin{array}{l}\text { Weeks } \\
\text { after } \\
\text { budbreak }\end{array}$ & $\begin{array}{l}\text { Basal stem } \\
\operatorname{diam}^{z}(\mathrm{~cm})\end{array}$ & $\begin{array}{l}\text { Rooting } \\
\text { percentage }\end{array}$ \\
\hline \multirow[t]{4}{*}{ 'Butterflies' } & 5 & $3.7 \mathrm{ef}$ & $3 \mathrm{bc}$ \\
\hline & 7 & $3.5 \mathrm{ef}$ & $0 \mathrm{bc}$ \\
\hline & 9 & $4.3 \mathrm{~d}$ & $3 \mathrm{bc}$ \\
\hline & 11 & $4.3 \mathrm{~d}$ & $0 \mathrm{bc}$ \\
\hline \multirow[t]{4}{*}{ 'Golden Sun' } & 5 & $4.5 \mathrm{~cd}$ & $31 \mathrm{~b}$ \\
\hline & 7 & $4.3 \mathrm{~d}$ & $16 \mathrm{~b}$ \\
\hline & 9 & $4.5 \mathrm{~cd}$ & $3 \mathrm{bc}$ \\
\hline & 11 & $4.6 \mathrm{~cd}$ & $3 \mathrm{bc}$ \\
\hline \multirow[t]{4}{*}{ 'Hot Flash' } & 5 & $4.6 \mathrm{~cd}$ & $22 \mathrm{~b}$ \\
\hline & 7 & $3.8 \mathrm{e}$ & $22 \mathrm{~b}$ \\
\hline & 9 & $4.4 \mathrm{~d}$ & $6 \mathrm{bc}$ \\
\hline & 11 & $4.3 \mathrm{~d}$ & $3 \mathrm{bc}$ \\
\hline \multirow[t]{4}{*}{ 'Ivory Chalice' } & 5 & $5.1 \mathrm{bc}$ & $41 \mathrm{ab}$ \\
\hline & 7 & $4.8 \mathrm{c}$ & $62 \mathrm{a}$ \\
\hline & 9 & $5.5 \mathrm{~b}$ & $56 \mathrm{a}$ \\
\hline & 11 & $5.8 \mathrm{a}$ & $25 \mathrm{~b}$ \\
\hline \multirow[t]{4}{*}{ 'Maxine Merrill' } & 5 & $3.0 \mathrm{~g}$ & $28 \mathrm{~b}$ \\
\hline & 7 & $3.2 \mathrm{~g}$ & $6 \mathrm{bc}$ \\
\hline & 9 & $3.6 \mathrm{ef}$ & $16 \mathrm{~b}$ \\
\hline & 11 & $3.9 \mathrm{e}$ & $0 \mathrm{bc}$ \\
\hline \multirow[t]{4}{*}{ 'Yellow Lantern' } & 5 & $5.1 \mathrm{bc}$ & $56 \mathrm{a}$ \\
\hline & 7 & $4.9 \mathrm{c}$ & 59 a \\
\hline & 9 & $5.4 \mathrm{~b}$ & 53 a \\
\hline & 11 & $5.3 \mathrm{~b}$ & $44 \mathrm{ab}$ \\
\hline $\operatorname{LSD}(\alpha=0.05)$ & & 0.2 & 18 \\
\hline
\end{tabular}

${ }^{\mathrm{z}}$ Means with the same letter within a column are similar as determined by Fisher's LSD $(\alpha=0.05)$.

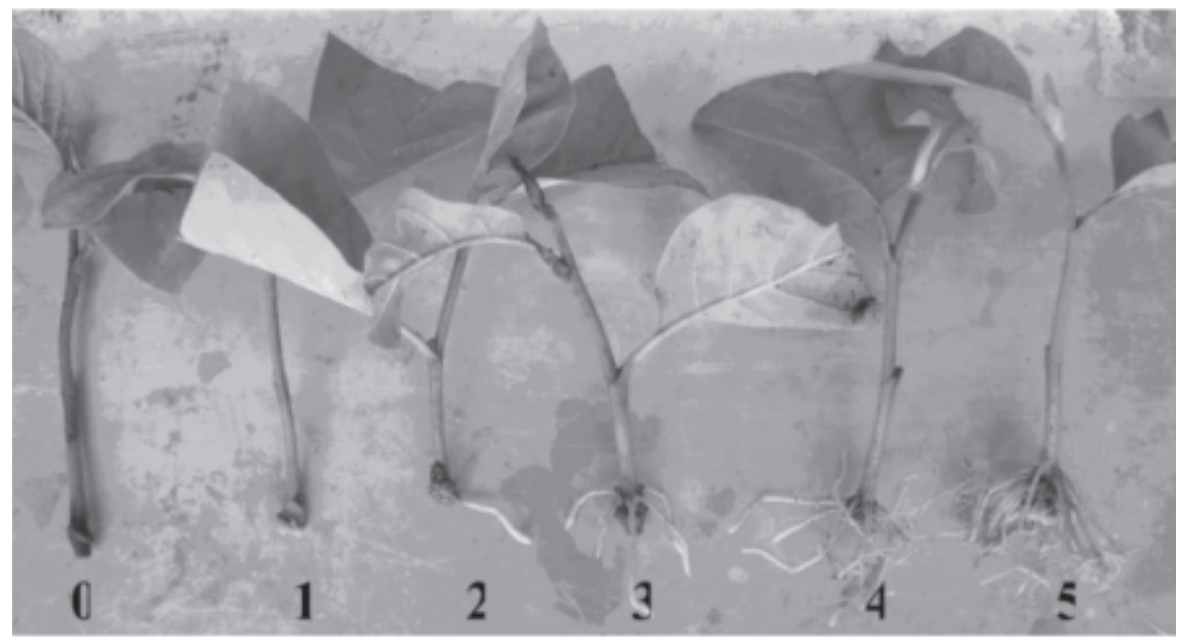

Fig. 1. Mean $(\mathrm{n}=32)$ rooting percentage among stem cuttings of yellow-flowered cultivars of magnolia collected at various dates after budbreak. Cultivar and collection date interacted to influence rooting, but IBA treatments $[0,8,16$, or $\left.30 \mathrm{~g} \cdot \mathrm{kg}^{-1}\right]$ did not produce statistical interactions with either. Means with the same letter are not significantly different as determined by Fisher's $\operatorname{LSD}(\alpha=0.05)$.

cuttings collected early in the growing season. Harvesting stem cuttings soon after budbreak also is beneficial for propagating other taxa, including Juglans cinerea L. (butternut) and Sequoiadendron giganteum (Lindl.) Buchholz (giant sequoia) (Berthon et al., 1987; Pijut and Moore, 2002). The difference in the capacity for in vitro vegetative regeneration among juvenile and mature cuttings of $S$. giganteum also was minimized by harvesting cuttings soon after budbreak (Monteuuis, 1987).

In response to IBA application, overall mean rooting percentage increased from $12 \%$ (untreated) to $34 \%$ ( $30 \mathrm{~g} \cdot \mathrm{kg}^{-1}$ IBA). A range from $5 \mathrm{~g} \cdot \mathrm{kg}^{-1} 20 \mathrm{~g} \cdot \mathrm{kg}^{-1}$ IBA is recommended for inducing root formation on cuttings of deciduous taxa of magnolia (Dirr and Heuser, 1987; Ellis, 1988; Hartmann et al., 2002). $\alpha$ Naphthalene acetic acid (NAA) also has been used to induce root formation among cuttings of several taxa of magnolia (Hartmann et al., 2002). Knox (2001) used a combination of IBA and NAA to induce rooting among some yellow-flowered cultivars, but the methods are not replicable. NAA, or a combination of IBA and NAA, could conceivably improve rooting among yellow-flowered cultivars of magnolia included in our study and should be tested, especially for taxa that remain unresponsive to IBA.

Developmental stage of cuttings also can influence the rooting capacity of woody plants (Graves, 2002; Hartmann etal., 2002; Pennington, 2001). In this study, basal stem diameter and rooting percentage were affected by an interaction between cultivar and collection date, but rooting percentage did not seem related to stem diameter at the base (Table 2).

Visual rating of roots, root count, and root length (longest single root) were influenced by two-way interactions between cultivar and collection date and between cultivar and IBA when all (rooted and unrooted) cuttings were included in the analyses. Dry weight of roots

Fig. 2. Development of roots on stem cuttings of yellow-flowered cultivars of magnolia ('Butterflies, ' Golden Sun,' 'Hot Flash, 'Ivory Chalice,' 'Maxine Merrill,' and 'Yellow Lantern') was rated visually by using values ranging from 0 to 5 , where $0=$ neither callus nor roots were observed on the base of the cutting, or the base was decayed; 1 = presence of callus but roots absent; $2=$ one or two roots $\geq 0.5 \mathrm{~cm}$ in length; $3=$ few, relatively short roots; $4=$ several, developed roots; and $5=$ many, well developed roots. 'Yellow Lantern' is shown in the image, but rooting is representative of all six cultivars. Number of roots also was recorded, and Pearson's correlation coefficient (PCC) was calculated to determine the relationship between the two variables. Visual rating and root count were correlated $(r=0.81, p<0.0001)$. 
was not affected by any treatment (data not presented). Root count and visual rating were positively correlated (Pearson's correlation coefficient $=0.81 ; p<0.01)$, but visual rating appears to be a better indicator of the overall size and health of the root system than does root count alone (Fig. 2). Mean rating was highest (2.5), roots were longer, and the largest number (mean $=5$ ) of roots developed on cuttings of 'Yellow Lantern' collected 5 weeks after budbreak or treated with $30 \mathrm{~g} \cdot \mathrm{kg}^{-1}$ IBA. Cuttings of 'Ivory Chalice' collected 7 weeks after budbreak received a mean rating of 2.5, but fewer $($ mean $=2.5)$ roots formed compared to 'Yellow Lantern.' Mean rating was $\leq 1.6$ and mean root count was $\leq 0.7$ among cuttings of 'Butterflies,' 'Golden Sun,' 'Hot Flash,' and 'Maxine Merill' regardless of collection date; roots also were shorter among these cultivars. Application of 16 or $30 \mathrm{~g} \cdot \mathrm{kg}^{-1}$ IBA generally improved the visual rating, number of roots, and root length among cuttings of 'Ivory Chalice' and 'Yellow Lantern.' Although callus was observed among cuttings of all cultivars, visual rating (mean $\leq 1.4$ ) and number of roots (mean

Fig. 3. Collection date influenced rooting percentage among stem cuttings of yellow-flowered cultivars of magnolia treated with $0,8,16$, or $30 \mathrm{~g} \cdot \mathrm{kg}^{-1}$ IBA in talc. Data were pooled over IBA treatments because an interaction between collection date and IBA was not detected $(n=32)$. Means with the same letter are not significantly different as determined by Fisher's LSD $(\alpha=0.05)$.
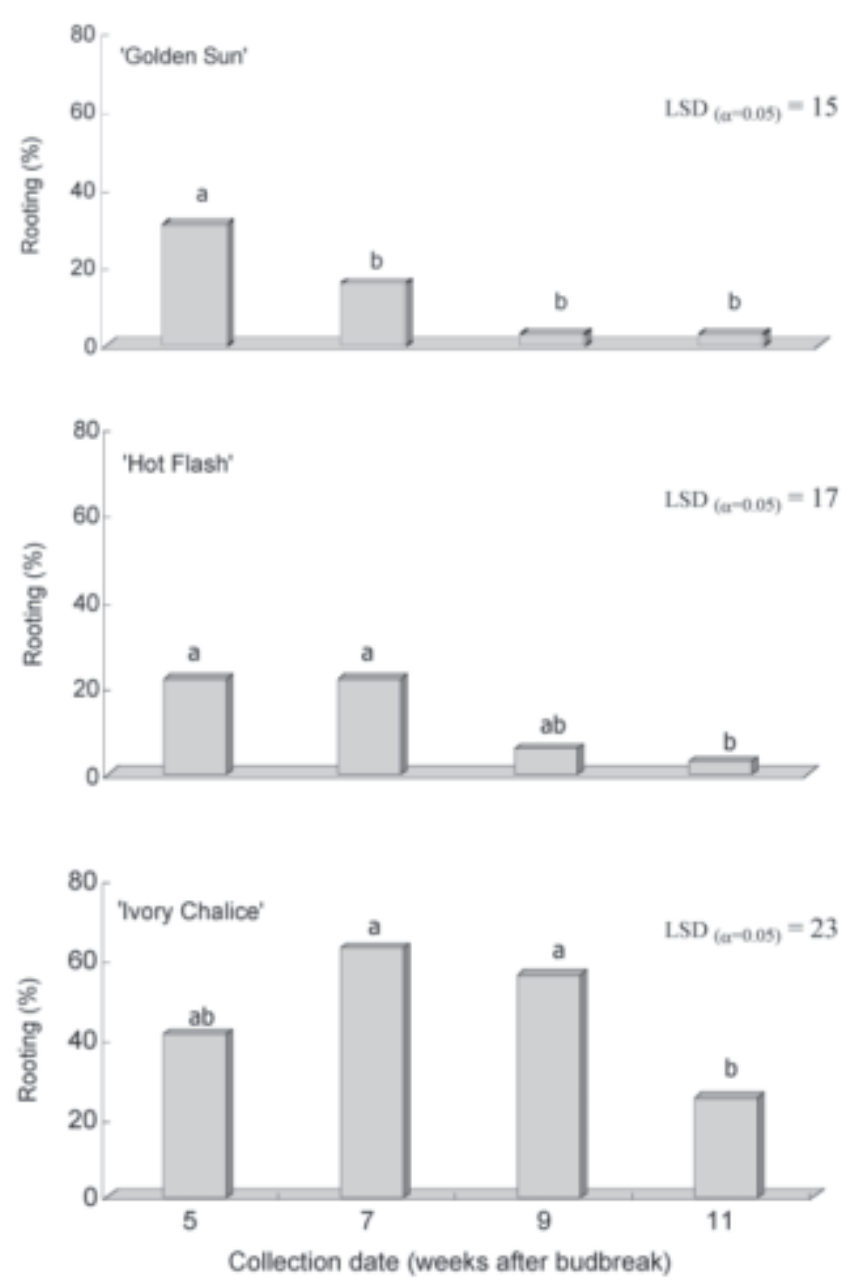

Table 3. Main effect of cultivar was observed on mean number of primary roots $[\geq 0.5 \mathrm{~cm}(0.2 \mathrm{in})$ in length] and mean length of the longest root among cuttings of yellow-flowered cultivars of magnolia collected $5,7,9$, or 11 weeks after budbreak to which $0,8,16$, or $30 \mathrm{~g} \cdot \mathrm{kg}^{-1}$ ) IBA was applied in talc. Means represent only the cuttings that formed at least one root.

\begin{tabular}{|c|c|c|c|}
\hline Cultivar & $\begin{array}{l}\text { Rooted } \\
\text { cuttings } \\
(\mathrm{n} / 128)\end{array}$ & $\begin{array}{c}\text { Primary } \\
\text { roots } \\
(\text { no. })^{z}\end{array}$ & $\begin{array}{c}\text { Longest } \\
\text { single } \\
\text { root } \\
(\mathrm{cm})\end{array}$ \\
\hline 'Butterflies' & 2 & $1.0 \mathrm{~b}$ & $2.5 \mathrm{c}$ \\
\hline 'Golden Sun' & 18 & $1.5 \mathrm{~b}$ & $5.1 \mathrm{~b}$ \\
\hline 'Hot Flash' & 17 & $2.3 \mathrm{~b}$ & $8.3 \mathrm{a}$ \\
\hline 'Ivory Chalice' & 59 & $3.4 \mathrm{ab}$ & $7.1 \mathrm{ab}$ \\
\hline 'Maxine Merrill' & 17 & $1.9 \mathrm{~b}$ & $6.7 \mathrm{ab}$ \\
\hline 'Yellow Lantern' & 69 & $5.7 \mathrm{a}$ & $5.6 \mathrm{~b}$ \\
\hline
\end{tabular}

${ }^{2}$ Means with the same letter within a column are similar as determined by Fisher's LSD $(\alpha=0.05)$. $\leq 0.7$ ) among cuttings of 'Butterflies,' 'Golden Sun,' 'HotFlash,' and 'Maxine Merill'were not influenced by IBA. Data described above (not presented in tabular form) represent both rooted and unrooted cuttings, but we also determined mean number of roots and mean root length after excluding unrooted cuttings from the data set. This should enable propagators to estimate the values they might achieve among the rooted cuttings only. For both dependent variables, a main effect of cultivar was observed. Cuttings of 'Yellow Lantern' produced twice the number of roots associated with any other cultivar. However, although only 17 of

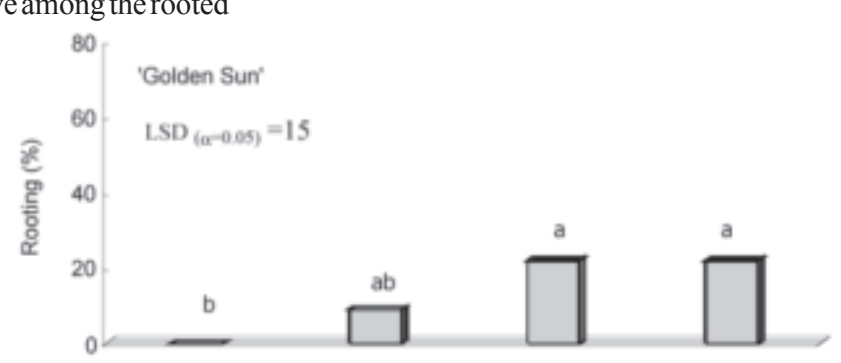

Fig. 4. IBA influenced rooting percentage among stem cuttings of yellow-flowered cultivars of magnolia collected $5,7,9$, or 11 weeks after budbreak. Data were pooled over collection dates because an interaction between collection date and IBA was not detected $(\mathrm{n}=32)$. Means with the same letter are not significantly different as determined by Fisher's LSD $(\alpha=0.05)$.
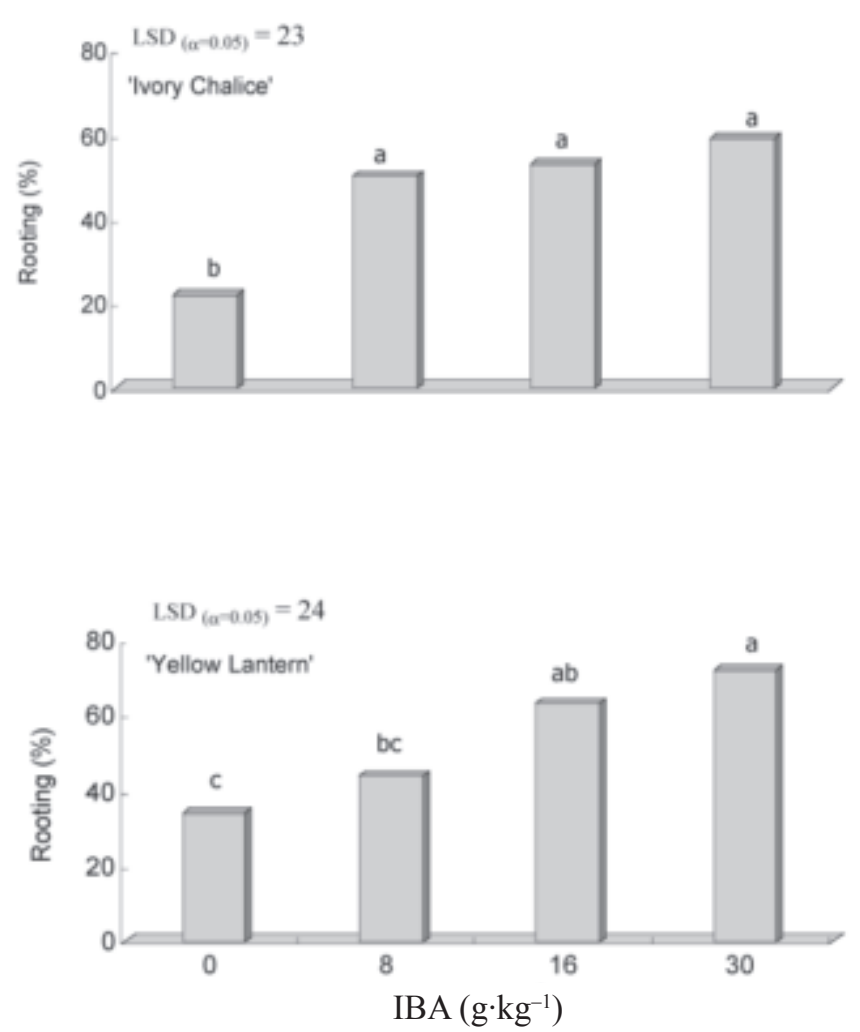
the 128 cuttings of 'Hot Flash' produced any roots, cuttings of this cultivar produced the longest roots $($ mean $=8.3$; Table 3$)$.

While comparisons among cultivars revealed the differences in their rooting capacity, analyses of data for selected cultivars allowed an assessment of the influence of collection date and IBA on rooting among cuttings of 'HotFlash,' 'Golden Sun,' 'Ivory Chalice,' and 'Yellow Lantern.' Collection date influenced rooting percentage among cuttings of 'Hot Flash,' 'Golden Sun,' and 'Ivory Chalice,' while IBA influenced rooting among cuttings of 'Golden Sun,' 'Ivory Chalice,' and 'Yellow Lantern.' Interaction between collection date and IBA concentration was not detected. Rooting percentage was higher among stem cuttings of 'Hot Flash' collected 5 or 7 weeks after budbreak ( $22 \%$ for both collection dates) compared to cuttings that were collected 11 weeks after budbreak (3\%; Fig. 3), but IBA application did not influence rooting among these cuttings. Collection date and IBA concentration influenced rooting percentage among cuttings of 'Golden Sun.' Harvesting cuttings earlier in the growing season ( 5 weeks after budbreak) was beneficial (rooting $=31 \%$; Fig. 3), while IBA applied at 16 or $30 \mathrm{~g} \cdot \mathrm{kg}^{-1}$ increased rooting percentage from 0 (control) to $22 \%$ (Fig. 4). Cuttings of 'Ivory Chalice' collected 7 or 9 weeks after budbreak rooted more frequently ( $63 \%$ and $56 \%$, respectively) than those collected 11 weeks after budbreak (25\%; Fig. 3). Application of IBA, regardless of the rate [8, 16, or $30 \mathrm{~g} \cdot \mathrm{kg}^{-1}$ IBA; Fig. 4], also improved rooting among cuttings of this cultivar (Fig. 4). A range of rooting percentages from $44 \%$ (11 weeks after collection) to $59 \%$ ( 7 weeks after collection) was observed among cuttings of 'Yellow Lantern;' these percentages were similar statistically, however (data not presented). IBA application improved rooting percentages in this cultivar, which ranged from $34 \%\left(0 \mathrm{~g} \cdot \mathrm{kg}^{-1} \mathrm{IBA}\right)$ to $72 \%$ (30 $\mathrm{g} \cdot \mathrm{kg}^{-1}$ IBA) (Fig. 4).

High rooting percentages among 'Ivory Chalice' and 'Yellow Lantern' cuttings indicate they are promising choices for growers interested in propagating yellow-flowered cultivars of magnolia. To maximize rooting among these cultivars, terminal cuttings should be collected within 5 to 11 weeks after budbreak and should be treated with 16 or 30 $\mathrm{g} \cdot \mathrm{kg}^{-1}$ IBA in talc.

Earlier collection dates (5 to 9 weeks) were more effective in inducing root formation among cuttings of 'Golden Sun,' 'Ivory Chalice,' and 'Hot Flash.' Because rooting percentage increased with increasing concentration of IBA, concentrations $>30 \mathrm{~g} \cdot \mathrm{kg}^{-1}$ could be tested to improve rooting, particularly among cultivars that remain recalcitrant. While our research identifies collection time and IBA concentrations for improving rooting percentages among stem cuttings of 'Ivory Chalice' and 'Yellow Lantern,' additional research is needed to identify optimal IBA concentration and collection date for rooting of 'Butterflies, ' 'Golden Sun,' 'Hot Flash,' and 'Maxine Merrill.'

\section{Literature Cited}

Berthon, J.Y., N. Boyer, and T. Gaspar. 1987. Sequential rooting media and rooting capacity of Sequoiadendron giganteum in vitro: Peroxidase activity as a marker. Plant Cell Rpt. 6:341-344.

Callaway, D.J. 1994. The world of magnolias. Timber Press, Portland, Ore.

Dirr, M.A. 1998. Manual of woody landscape plants: Their identification, ornamental characteristics, culture, propagation, and uses. 5th ed. Stipes Publ., Champaign, Ill.

Dirr, M.A. and C.W. Heuser, Jr. 1987. The reference manual of woody plant propagation: From seed to tissue culture. Varsity Press, Athens, Ga.

Ellis, D.G. 1988. Propagating new magnolia cultivars. Proc. Intl. Plant Prop. Soc. 38:453-456.

Graves, W.R. 2002. IBA, juvenility, and position on ortets influence propagation of carolina Buckthorn from softwood cuttings. J. Environ. Hort. 20:57-61.

Hartmann, H.T., D.E. Kester, F.T. Davies, Jr., and R.L. Geneve. 2002. Hartmann and Kester's plant propagation: Principles and practices. 7 th ed. Prentice Hall, Upper Saddle River, N.J.

Knox, G.W. 2001. New and improved deciduous magnolia cultivars. Proc. Intl. Plant Prop. Soc. 51:601-603.

Monteuuis, O. 1987. In vitro meristem culture of juvenile and mature Sequoiadendron giganteum. Tree Physiol. 3:265-272.

Owen, Jr., J., W. Johnson, and B. Maynard. 2001. Cutting propagation screening trials at University of Rhode Island. Proc. Intl. Plant Prop. Soc. 51:514-516.

Pennington, T. 2001. Propagating magnolias in Tennessee. Magnolia: J. Magnolia Soc. 36:11-15.

Pijut, P.M and M.J. Moore. 2002. Early season softwood cuttings effective for vegetative propagation of Juglans cinerea. HortScience 37:697-700.

Tessmer, R.G. 1998. From butter to cream: Magnolia. J. Magnolia Soc. 33:19-20. 